\begin{tabular}{|l|l|l||}
\hline \multicolumn{2}{|c|}{ PublisherInfo } \\
\hline \hline PublisherName & $:$ & BioMed Central \\
\hline \hline PublisherLocation & $:$ & London \\
\hline \hline PublisherImprintName & $:$ & BioMed Central \\
\hline \hline
\end{tabular}

\title{
Breast Cancer on CancerNet
}

\begin{tabular}{||l|l|l||}
\hline \multicolumn{2}{|c||}{ ArticleInfo } \\
\hline \hline ArticleID & $:$ & 3669 \\
\hline \hline ArticleDOI & $:$ & $10.1186 /$ bcr-2000-2-webreport0001 \\
\hline \hline ArticleCitationID & $:$ & 0001 \\
\hline \hline ArticleSequenceNumber & $:$ & 35 \\
\hline \hline ArticleCategory & $:$ & Web Report \\
\hline \hline ArticleFirstPage & $:$ & 1 \\
\hline \hline ArticleLastPage & $:$ & 3 \\
\hline \hline & & $\mid$ RegistrationDate : 2000-1-28 \\
ArticleHistory & $:$ & OnlineDate $: 2000-1-28$ \\
\hline \hline ArticleCopyright & $:$ & Current Science Ltd2000 \\
\hline \hline ArticleGrants & $:$ & \\
\hline \hline ArticleContext & $:$ & 1305822 \\
\hline \hline
\end{tabular}




\section{Overview}

CancerNet is a service provided by the National Cancer Institute and is aimed primarily at US and Canadian citizens. The site contains a wealth of information relating to breast cancer (including an extensive section on genetics) and all other types of cancer.

One particularly useful aspect of this site is the clinical trials database. You can search for clinical trials for male or female breast cancer by the following type of trial: treatment; prevention; diagnosis; genetics; screening; supportive care. You can then read the trial as a healthcare professional or as a patient. A search for currently active supportive care breast cancer trials displayed 25 choices.

Users of CancerNet have access to a directory of breast cancer specialists (including cancer genetics professionals) in the US and Canada.

Another service is the breast cancer risk assessment tool. This consists of a computer program that women and their healthcare providers can use.

This site can also be viewed in Spanish.

\section{Content}

The site is fully searchable and extremely easy to navigate even for beginners, with very few broken links. The site contains an extensive list to related external websites.

\section{Other comments}

The website appears to be updated regularly but there is no information regarding latest time of update.

\section{Evaluation}


The site provides general information on all cancer related issues. It may not go into enough detail for some users, although the comprehensive list of links leading to specialist sites makes this a good starting point. The layout of the site, although easy to navigate, would benefit from some clickable graphics, as the bulk of text makes it tedious at times.

By far the best feature of this site is that you can read much of the information as a professional or a patient. This means that the level of expertise needed to use the site can vary.

\section{References}

1. CancerNet. [http://cancernet.nci.nih.gov/cancer_types/breast_cancer.shtml] 